Vol. 4, No. 1, January 2016

Jurnal llmial

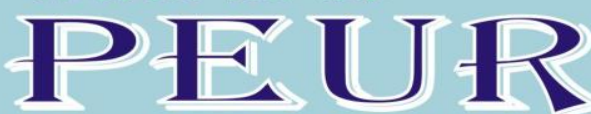

Media Kajian Ilmiah Sosial, Politik, Hukum, Agama dan Budaya
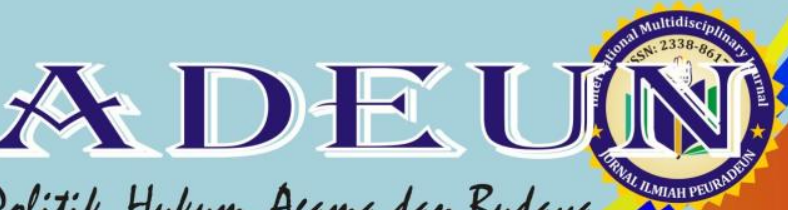


\title{
REDUPLICATION IN THE LOCAL LANGUAGE PAK-PAK BOANG SUBULUSSALAM CITY, ACEH PROVINCE, INDONESIA
}

\author{
Yulsafli \\ Serambi Mekkah University Banda Aceh, Indonesia \\ E-mail:yulsalfi@gmail.com
}

Received: May 20, 2015

Accepted: Sept 4, 2015

Published: Jan 21, 2016

Article Url: https://journal.scadindependent.org/index.php/jipeuradeun/article/view/87

\begin{abstract}
This paper examined the reduplication of Pak-Pak Boang language which consists of many reduplication, the speakers of the language are situated in the Rundeng, Subulussalam, Aceh Province. The research aspects to explore are types of reduplication and the forms produced through the reduplication of the language. The purpose of this paper is to describe the types and forms of Pak-Pak Boang language. The method applied in this research was qualitative descriptive, where the data gained through recording, documentary study, and introspection. The result of the findings showed that Pak-Pak Boang language reduplication consisted of four types: Phonology, syntaxes, semantics, and morphology reduplication. The second finding revealed that the reduplication forms were Dwilingga, Dwipurwa, Dwiwasana, and trilingga reduplication, while the process to form reduplication consisted of seven ways: Adjective, Verb, noun, Pronoun, Adverb, Interrogative, and Number reduplication.
\end{abstract}

Keywords: Pak-Pak Boang Language, Reduplication, Subulussalam 


\section{A. Introduction}

Pak-Pak Boang is one of the languages which consist of variety reduplication. The types of reduplication are Verb, Noun, Adjective, Number and Pronoun. The above description showed a morphology process that the repetitions itself were consisted of partial and whole. Reduplication is grammatical repetition unit as a whole or partial process, through variety of phonemes or none. Reduplication is the process of word reputation, in which the repeated words is root word (Ramlan, 1985: 57).

Reduplication is a morphemic process in which the root words repeated as a whole, partial or sound alteration. (Chaer, 1994: 182). Repetition or reduplication is the process of word reduction. (Alwi, 2003: 238). A repetitive word goes through repetition as a whole or partial process or followed by sound changing (Kosasih, 2008: 134). The urgency of this research will produce materials in the form of theory and rules of reduplication of PakPak Boang obtained from native speakers. The theory and rules therefore will be very useful for the documentation of Pak-Pak Boang, since the language is nearly extinct and has not been investigated thoroughly. In general, this research is also valuable for enriching the scientific languages archipelago in Indonesia. the languages in which few native speakers left - including Pak-Pak Boang language -is required to research and document so that when speakers of the languages die off, the languages will still exist, even though through documentation that enrich the wealth of cultural treasures of Indonesia

\section{B. Method}

The method applied in this research is descriptive qualitative, where the researcher took a note, record all the information observed or gathered through the native speakers. The method relied on the issue existed by elaborating the reality systematical, actual and factually. The techniques used were recording, documentary study and Introspection.

\section{Research Finding}

The language has variety of reduplication. It is varied in forms and rules which could be seen on the following explanation. 


\section{The types of reduplication in Pak-Pak Boang}

\section{a. Phonological Reduplication}

1) Silu-silu 'Nails'

2) Da-da 'da-da'

Silu-silu, lae-laea, form which comes from the repetition of basic word. These are forms which sound the same and generate lexical meaning.

Example:

a) Silu-silu na gedang kekhina. 'All the nails broke.'

b) sang luak hapona buk-buk mesekhaken. 'Hairs are in all over the place.'

b. Syntax reduplication
1) Ulang
'perhaps'
2) Tuhu-tuhu
'truly'

Repetitive word, ulang-ulang, tuhu-tuhu are the form of words which have the same meaning but one word usually has higher status.

Example:

a) Ulang-ulang desingi ko kaumna. 'don't approach his relative'

b) Adikna tuhu-tuhu pehangke' his brother is lazy'

c. Sematic reduplication

1) tua khenta 'elder'

2) nokhok malim 'smart

Tua khenta, nokhok malim these are the repetition of meaning from two synonyms.

Example:

a) Bapakna Enggo Tua Khenta. His father is old.

b) Ia mencekhok dos bage kalak nokhok bak malim. 'He speaks like a smart man.'

\section{d. Morphology reduplication}

1) Menakha-nakhai

'menyapu-nyapu'

2) Menulus-nulus

'mencari-cari'

Menyakha-nyakha, menulus-nulus these are the type of morphology words which can happen in the base of words 
Example:

a) Umak sedang menakha-nakhai sang tukhe sapo.

Mother is sweeping in the house

b) Enggo udan, bakhu tohna sibuk menulus-nulus payung

When it has started to rain he is looking for umbrella

\section{The type of Pak-Pak Boang's reduplication}

\section{a. Dwilingga (whole repetition)}

1) Ndaoh-ndaoh 'away'

2) Khebak-khebak 'together'

Ndaoh-ndaoh, khebak-khebakthese are the form of dwilinga repetition which does not change the root of base verbs

Example:

a) Ndaoh-ndaoh aku khoh paen asa menengen ko

I came all the way here to see you

b) Kekhajo en khebak-khebak kita menyiapkenna.

We should finish this job together.

b. Dwipurwa (Partial repetition)

1) Leluhukh 'Ancestors'

2) Dedeholi 'Man'

Leluhukh, dedoholi, these are the form of Dwipurwa (Partial repetition) which repeat only the base of the word.

Example:

a) Anak-anak pekhana sehakhusna mengikuti jejak leluhukh kita.

'Young people should follow the elders steps.'.'

b) Zaman begenden anak dedeholi oda bisa ne dipecaya khatana.

'Nowdays young men can't all be trusted'.

\section{c. Dwilingga Salin Suara (Repetition with sound altereation)}

1) khamah-tamah 'Courtesy'

2) kekhlap-kekhlip 'sparkling'

Khamah-tamah, kekhlap-kekhlipthese are words whose sounds can change the consonants and the voice.

Examples:

a) Pekhtemuan idi diisi bak acakha khamah-tamah.

'The meeting is filled with courteous acts 
b) Hapona dihiasi bak kekhlap-kekhlip lampu hias.

'The house is adorned with sparkling lampshias'

\section{d. Dwiwasana}

1) Tekejut-kejut 'shocked'

2) Mewakhi-wakhi 'days'

Tekejut-kejut, mewakhi-wakhiare dwisana repetition, the repetition of the rear leksem

Example:

a) Mebege kabakh ia enggo mate mbue kalak tekejut-kejut.

'People were shocked upon hearing his death'

b) Enggo Mewakhi-wakhi umak oda balik mi hapo.

“I haven't gone home for days'

\section{e. Trilingga}

1) Dak-dekh-dokh 'dar-der-dor'

2) Ngak-ngek-ngok 'ngak-ngek-ngok'

Dakh-dekh-dokh, ngak-ngek-ngokare trilingga repetition, the repetition of base words three times.

Example:

a) Dakh-dekh-dokh sokha senapang kalak mepekhang

'Dar-der-dor guns sound went off'

b) Ngak-ngek-ngok sokha anak dukak tangis.

'Dag-dig-dug my heart Is beating hard when I see that girl'

\section{The forming of reduplication}

a. Verbs reduplication

1) Hanjakh-hanjakh 'slowly'

2) Tokh-tokh 'quickly'

Hanjakh-hanjakh, tokh-tokhare the repetition of Verbs reduplication which can be generated in the process of reduplication.

Example:

a) Hanjakh-hanjakh sambin letakken pikhingi.

Put the plates down slowly.

b) Tokh-tokh kona khoh mi sapo ku segen.

Come to the house quickly tomorrow. 


\section{b. Adjective reduplication}

1) Mbekhu-mbekhu 'beautiful.'

2) Mende-mende 'good'

Mbekhu-mbekhu, mende-mendeare the reduplication which form roots, derivative, and conjunction.

Example:

a) Kekhina anakna pate kelek mbekhu-mbekhuna.

'All the girls are beautiful.'

b) Pekhange anak pekhana sang kampong idi mende-mende.

'He behavior of young people in that village is good

c. Noun reduplication

1) Sayukh-sayukhen 'vegetables

2) Tetangga 'neighbors'

Sayukh-sayukhen, tetangga, langit-langit. The reduplication form of grammatical meaning nouns which bore states.

Examples:

a) Kekhina kalak sekel kepangan sayukh-sayukhen.

'People love vegetables.'

b) Tetangga hapoku khamah kekhina.

'My neighbors are all friendly.'.'

\section{d. Pronoun reduplication}

1) Ia-ia

'Him'

2) Kalak-kalak.

'People'

Ia-ia, kalak-kalakare the reduplication form of an affirmation stating pronouns

Example:

a) Ia-ia sambin keca kena kekhajo sitabohna.

‘He always has good job.

b) Kekhina kalak-kalak si membangkang dihukum.

'All rebels will be punished.'

\section{e. Adverb reduplication}
1) Sada-sada
'satu-satu'
2) Telu-telu
'tiga-tiga' 
Sada-sada, telu-teluare the reduplication of adverb as a reduplicated noun. Example:
a) Sada-sada embahken bakhangna.
'Each of you carry the stuff
b) Kekhina dapet hadiah telu-telu
'The three of them got gifts"

\section{f. Interogative reduplication}

1) Kade-kadeen 'apa-apaan'

2) Asal-asalen 'asal-asalan'

Kade-kadeen, asal-asalen are the reduplication of Interogative reduplication.

Example:

a) Kade-kadeen ko khoh mi sapoku bekhngin-bekhngin begen.

'How dare you came to my house tonight..'

b) Oda mende karena kekhajona asal-asalen hambin.

'The quality of the work is not good'.'

\section{g. Number reduplication}

1) Mepuluh-puluh 'thousand

2) Sekhatus-khatus 'hundreds'

Mepuluh-puluh, sekhatus-khatusare the reduplication of number.

Example:

a) Mepuluh-puluh jokhma menema kepeng pembagien zakat.

'They all wait for welfare.'

b) Kekhina dapet sekhatus-khatus.

'They all have hundreds.'

\section{Reduplication Meaning}

\section{a. Repetitive Meaning}

Repetitive Meaning'being repeated all the time" regarding the reduplication of Pak-Pak Boang Language.

1) Medalan-dalan 'take a stroll

2) Mangan-mangan 'eating'

Medalan-dalan, mangan-manganare words which are often used that have repetitive meaning. 
Example:

a) Kekhajona setiap wakhi medalan-dalan.

'His job is just taking a stroll everyday'

b) Anak-anaki hampekh setiap jam agakna mangan-mangan sambin.

'All his kids want is to eat.

\section{b. Various Meaning}

Repetition is done not only with base vorbs but also with the meaning of base verbs in Pak-Pak Boang.

1) Khame-khame 'rame-rame'

2) Mbue-mbue 'banyak-banyak'

Khame-khame, mbue-mbue, kalak-kalakare words that are widely used in speech acts or deeds that are done by more than one person.

Example:

a) Penangko idi kena kekhoyok khame-khame.

'The mob beat the thief.'

b) Kekhina anakna mbue-mbue dapet wakhisen.

'His kids get lots of inheritence'.'

\section{c. Resiproke Meaning}

Repetition of words to have Resiproke Meaning which is done to the reduplicated verbs in Pak-Pak Boang.

Example:

1) Cokhat-cokhet 'Scribled

2) Kekhlap-kekhlip 'Sparkling'

Cokhat-cokhet, kekhlap-kekhlip, khamah-tamahare words which have Resiproke Meaning.

Example:

a) Bukuna kekhina habis tecokhat-cokhet.

'The books are all scribbled'.'

b) lampu sang mesjid kekhina mekekhlap-kekhli.

'The lamps in mosque are all sparkling'.

\section{d. Process Meaning}

Repetition to have Resiproke Meaning is done with verbs, in the form of reduplication based on the meaning the words created. 
1) Gupak-megupak 'Beating up'

2) Menengen-nengen 'Sightseing'

Gupak-megupak, menengen-nengenare words which create specific meaning.

Example:

1) Anak sekolah si mekhubat i tekhus gupak-megupak.

'The kids from school are involved in fighting.'

2) Kekhina kalak menengen-nengen anak menguda si mbekhu idi. 'People see that beautiful girl.'

\section{e. Sudden Meaning}

Repetition of the sudden meaning is done to the reduplicated verbs. Example:

1) Medetak-detak 'Beating hard'

2) Tegejut-gejut 'shocked'

Medetak-detak, tegejut-gejutare repetition of words which create specific meaning depending on the spoken words.

Example

a) Jantungku medetak-detak cepet waktu kubege kona menenggo aku. 'My heart beat so fast when you called me'

b) Kekhina kalak tekejut-kejut waktu mege ia enggo mate.

'People were all surprised upon hearing his death.'

\section{f. Miscellaneous Meaning}

Repetition of words to have Miscellaneous Meanings performed to the verbs in the form of reduplication in Pak-Pak Boang Language.

1) Mehembus-hembus 'Blowing'

2) Mekhasa-khasa 'Feeling'

Mehembus-hembus, mekhasa-khasaare repetition words in Pak-Pak Boang which form simple words.

Example:

1) Angin mehembus-hembu sang tepi pante gosong telaga.

'The wind blew in gosong telaga beach'.

2) Unyak mekhasa-khasa khokhoh sang belanga pate kelek tabohna

'My sister tasted the delicious gravy in the pot.' 


\section{g. Feeling Meaning}

Repetition of words to have feeling meaning is performed to the verb in Pak-Pak Boang language.

1) Memangan-mangan

2) Diencep-encep 'Eating'

Memangan-mangan, mengencep-ngencepare repetition which have the meaning of feeling according to the context of words spoken by others.

Contoh kalimat:

1) Kekhina undangen sang bekas pesta idi memangan-manganen sitabohna

'The food in the party was delicous.'

2) Hakhu tabohna khokhona bak kuahna diencep-encepna 'He sips the gravy because it was so good.'

\section{Discussion}

Pak-Pak Boang is one of language that still exists in Aceh Province which is located in Rundeng, Subulussalam. The language has uniqueness in term of reduplication. Pak-Pak Boang is the language has variety of root word repetition, such as Noun, Verb, Adjective, Adverb, Number and Pronoun in which this word reduplicated in the areas of Phonology, Morphology, Semantic and Syntax. This reduplication is similar to Bahasa, but less in types and forms.

Pak-Pak language is limited in written data. So far, there is no literature review documented toward this language in which the researcher suggest for further investigation toward this language as the process of perpetuation of national treasure in the form of language.

\section{E. Conclusion.}

Having completed a research on "the reduplication of Pak-Pak Boang" which was done to the community of kampung Rundeng, Subulussalam, the writer found that the reduplication of words based on the types are:

1) Phonology reduplication

2) syntax reduplication

3) Semantic reduplication 
4) Morphology reduplication.

The forms of reduplication of Pak-Pak Boang are;

1) Dwilingga reduplication,

2) Dwipurwa reduplication,

3) Dwilingga reduplication,

4) Dwiwasana reduplication,

5) Trilingga reduplication.

The processes of forming reduplication are as follow:

1) Verbs reduplication

2) Adjective reduplication

3) Noun reduplication

4) Pronoun reduplication

5) Adverb reduplication

6) Interrogative reduplication, and

7) Number reduplication.

\section{Bibliography}

Akbar, Osra M. (1985). Pemetaan Bahasa Aceh, Gayo dan Alas. Jakarta: Pusat Pembinaan dan Pengembangan Bahasa Departemen Pendidikan dan Kebudayaan.

Alwasilah. A. Chaedar. (1985). Teori Linguistik. Bandung: Angkasa.

Alwi, Hasan. dkk. (2003). Tata Bahasa Baku Bahasa Indonesia. Jakarta: Balai Pustaka.

AR, Syamsuddin dan Visma S. Damaianti. (2006). Metode Penelitian PendidikanBahasa. Bandung: Remaja Rosdakarya..

Badudu, J. S. dan Muhammad Zain. (1996). Kamus Umum Bahasa Indonesia. Jakarta: Pustaka Sinar Harapan.

Badan Pusat Statistik Aceh Singkil (2008). Sejarah Kota Subulussalam. singkil: BPS Singkil.

Cahyono, Bambang Yudi. (1994). Kristal-Kristal Ilmu Bahasa. Malang: Airlangga University Press.

Chaer, Abdul. (2008). Morfologi Bahasa Indonesia: Pendekatan Proses. Jakarta: Rineka Cipta. 
. 2007. Kajian Bahasa: Struktur Internal, Pemakaian dan Pemelajaran. Jakarta: Rineka Cipta. 2006. Tata Bahasa Praktis Bahasa Indonesia. Jakarta: Rineka Cipta. . 2002. Pengantar Semantik Bahasa Indonesia. Jakarta: Rineka Cipta. 1994. Linguistik Umum. Jakarta: Rineka Cipta.

Departemen Pendidikan Nasional. (2001). Kamus Besar Bahasa Indonesia. Jakarta: Balai Bahasa.

Keraf, Gorys.(1994). Komposisi. Jakarta. Nusa Indah.

Moleong, Lexy J. (2007). Metodologi Penelitian Kualitatif. Bandung: Remaja Rosdakarya.

Nawawi, Hadari. (1991). Metode Penelitian Bidang Sosial. Yogyakarta: Gajah Mada University Press.

Rajab, T. (2015). An Applied Model of Teaching Materials to Improve Students' Speaking Skill. Jurnal Ilmiah Peuradeun, 3(1), 103-118.

Sulaiman, Budiman. (1977). Bahasa Aceh. Banda Aceh: Departemen Pendidikan dan Kebudayaan.

Tumangger, suku Pak-Pak. (http: //. www @yahoo.com, diakses 18 Februari 2011).

ZA, T. (2014). Islamic Studies dalam Pendekatan Multidisipliner (Suatu Kajian Gradual Menuju Paradigma Global). Jurnal Ilmiah Peuradeun, 2(2), 211-234. 